\title{
コンクリート中の鉄筋の応力腐食割れ STRESS CORROSION CRACKING IN REBARS IN CONCRETE
}

\author{
山中憲行*, 林貞夫**, 澤田友理恵***, 松島 巌**** \\ Noriyuki YAMANAKA, Sadao HAYASHI, Yurie SAWADA \\ and Iwao MATSUSHIMA
}

\begin{abstract}
A study of carbonate stress corrosion cracking in rebars has been carried out in the laboratory to investigate the cause of cracking/fracture that actually occurred in rebars in ASR-affected concrete. Cracking was reproduced in potassium carbonate-sodium bicarbonate solutions in concentrations realistic in ASR-affected concrete. The specimens were maintained at potentials that promote cracking. The occurrence of cracking in the simulated system shows a high possibility that the carbonate stress corrosion cracking is the cause of the failure in service.
\end{abstract}

Keywords : Rebars, Carbonate stress corrosion cracking, Hydrogen cracking, Caustic embrittlement, ASR 鉄筋，炭酸塩応力腐食割れ，水素脆化，アルカリ脆化，アルカリ骨材反応

\section{1. はじめに}

せん断補強筋の曲げ加工部の破断がコンクリートのアルカリ骨材

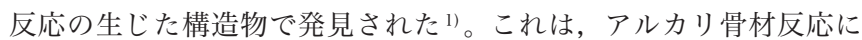
よる過大な膨張力が鉄筋に加わったことによって破断したと考えら れた。しかし，アルカリ骨材反応の生じた構造物の竣工と同時期の 1960年代に発表された論文2),3)では, 事例の鉄筋の曲げ半径と同程度 の公称直径の 1.8 倍1) およびそ扎より大きな曲げ半径で 90 度に折り曲 げたのちに曲げ戻した鉄筋が破断していない。鉄筋単体の試験では あったが, 事例の曲げ半径より極端に小さなものでなければ膨張力の みでは破断が起こらないと考えられる。さらに, 膨張力による破断の

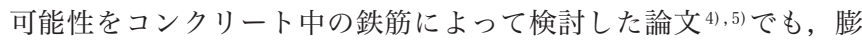
張力のみでは破断が起こらないことを示唆している。したがって, 事例の鉄筋は引張強さ以下の応力で破断が生じたと考元られるが, その破断原因は特定されていない。アルカリ骨材反応の生じていな い一般的な鉄筋コンクリート構造物においても鉄筋破断の生じる可 能性があり, 引張強さ以下で鉄筋が破断する要因を検討していくこ とは非常に重要である。

そこで, 付加応力が引張強さ以下でコンクリート中の鉄筋に破断 が生じうるのは何らかの腐食割れであるが, 腐食割れを生じさせる 化学因子を特定する場合には割れ感受性を有しそうな化学因子を考
えて環境面や割れ経路からの検討を行ったあとに, 試験室的に割れ 感受性を確認するという流れが一般的である。その流れに従うと， コンクリート中の鉄筋に腐食割孔が生じうるのは炭酸塩応力腐食割 れ，水素脆化，アルカリ脆化である。塩化物イオンの作用による炭 素鋼の応力腐食割れの事例は極めて限られるが, 海洋大気や塩水中 の高張力鋼 (降伏強さ $>1230 \mathrm{~N} / \mathrm{mm}^{2}$ ) の割れ $\left.{ }^{6)}, 7\right)$, 沸騰 $45 \% \mathrm{MgCl}_{2}$ 中での 低 $\mathrm{Ni}$ 鋼 $(\mathrm{Ni}$ : 約 $1 \%$ 以上) の割れ8) などが報告され，普通強度の鉄筋で は割れが生じえないので，本研究では対象としない。

ここで対象とした 3 種の腐食割れのうち環境面から考えた場合, 水素脆化はコンクリートがアルカリ性であること，事例の鉄筋が SD30であり, 高力ボルトの割れ事例などから, 普通強度の鉄筋では 強度的にコンクリート中で割れが生じる材料である可能性が低い。 また，アルカリ脆化はコンクリート中で割れが生じるにはアルカリ 濃度及び温度ともに低い。他方, 炭酸塩応力腐食割孔は, 従来の文 献には鉄筋の割れ要因として注目した例が存在しないが, 次の理由 によりコンクリート中の鉄筋で割れの生じる可能性がある。

（1）破断事例のコンクリートはアルカリ骨材反応が生じていたこと から，同時に中性化が進んでいたと考えられる 性化が進んだコンクリートでは割机発生に十分な量の炭酸塩が 生成されやすい環境であった可能性が高い。

\footnotetext{
$*$ 前橋工科大学工学部建築学科 助教 $\cdot$ 修士 $($ 工学 $)$

Assist. Prof., Department of Architecture, Faculty of Engineering, Maebashi Institute of

** 前橋工科大学工学部建築学科 教授·工博

*** (有)司構造計画事務所

**** 前橋工科大学 名誉教授・工博

（日本鋼管侏社友会会員）

\author{
Technology, M. Eng. \\ Prof., Department of Architecture, Faculty of Engineering, Maebashi Institute of Technology, \\ Dr. Eng. \\ Tsukasa Structural Design Limited
}

Prof. Emeritus, Maebashi Institute of Technology, Dr. Eng.
} 
(2) 鉄筋の破断事例の報告 ${ }^{10)}$ によれば, 割れの先端は粒界に沿って 進行している粒界型とされているが, 報告写真の割れの一部に, 結晶粒を貫通して進行する粒内型が存在しているょうである。 破断事例の経路は粒界 - 粒内混合型であった可能性が極めて高 く, 混合型となりうるのは検討対象の中では炭酸塩応力腐食割 れのみである ${ }^{11)}$

本研究では, 中性化したコンクリートを模擬した環境中で, 鉄筋 の炭酸塩応力腐食割れを再現することにより, 炭酸塩応力腐食割れ が鉄筋に生じうるかを検討した。また，水素脆化がコンクリート中 の鉄筋で生じうるかを明らかにした文献がないことから, 本研究で は促進環境での水素脆化による割れ感受性の有無を調査した。併せ て，アルカリ脆化による割れ感受性の有無も調査した。

\section{2. 炭酸塩応力腐食割れ試験}

\section{1 試験概要}

応力腐食割れ試験はいくつかの試験方法があるが, 鉄筋に対する 事例がないため, JIS G0576のステンレス鋼の応力腐食割れ試験方 法 ${ }^{12)}$ を参考に試験体を作製した。試験体には表 1 の異形鉄筋 D 13 (SD295A) を使用した。試験体は異形鉄筋のリブと節を除去したのち 500 番の研磨紙で直径 $11.6 \mathrm{~mm}$ まで磨き, 深さ $2.5 \mathrm{~mm}$ の 字型ノッチ を入れたのち, 曲げ半径 $15 \mathrm{~mm}$ (直径の 1.3 倍) で 180 度に曲げて, 金具 によって端部を固定し, 写真 1 の字型試験体を作製した。試験は 図1のような構成で行った。溶液はカリウムとナトリウムを含むコ ンクリートが炭酸化した状態を模して, $0.5 \mathrm{~mol}^{2} \mathrm{~L} \mathrm{~K}_{2} \mathrm{CO}_{3}-1.0 \mathrm{~mol} / \mathrm{L}$ $\mathrm{NaHCO}_{3}$ 混合溶液 (pH9.1), 及び $0.5 \mathrm{~mol}^{2} \mathrm{~L} \mathrm{~K}_{2} \mathrm{CO}_{3}-1.5 \mathrm{~mol} / \mathrm{L} \mathrm{NaHCO}_{3}$ 混合溶液 (pH9.5) の2種類とし, $80^{\circ} \mathrm{C}$ の温度で別に定めた電位に保持 した。また，コンクリート中の鉄筋にマクロ腐食電池が生じる場合 はその電流の大きさによって分極電位が様々な值になると考えられ るが, 電位は酸洗いを行った試験体に $0.2 \mathrm{mV} / \mathrm{sec}$ の掃引速度で分極 曲線の測定から求めた割れの生じやすい電位值とした。照合電極は 飽和カロメル電極を用いた。

\section{2 試験結果}

(1) 分極曲線

分極曲線の測定結果を図2に示す。電流密度の変化が大きい領域で応 力腐食割孔感受性が高い13) ことから, $0.5 \mathrm{~mol} / \mathrm{L}-1.0 \mathrm{~mol} / \mathrm{L}$ 溶液では飽 和カロメル電極基準 (以後, vs SCE) で- $670 \mathrm{mV}, 0.5 \mathrm{~mol} / \mathrm{L}-1.5 \mathrm{~mol} / \mathrm{L}$ 溶液では-660mV (vs SCE) に設定して応力腐食割れ試験を行った。

\section{(2) 応力腐食割孔試験}

$0.5 \mathrm{~mol} / \mathrm{L}-1.0 \mathrm{~mol} / \mathrm{L}$ 溶液では試験開始から190時間後に, $0.5 \mathrm{~mol} / \mathrm{L}-$ $1.5 \mathrm{~mol} / \mathrm{L}$ 溶液では200時間後に試験体の割れ状況を目視によって観 察した。割れは両方の溶液で生じた (写真2)。試験体を研磨して, 内 部の割れ経路を金属顕微鏡によって観察を行った。割れ経路は写真 3のように応力腐食割れの特徵である河川分岐状に広がっていた。更 に倍率を上げて観察を行うと, 割れの先端を含めて写真 4 のような 粒界に沿って進行する粒界型が主体的であり, 割れの途中には写真 5のような結晶粒を貫通して進行する粒内型が一部に存在した。

\section{3. 炭酸塩応力腐食割れが生じる可能性}

\section{1 環境面からの考察}

炭酸塩によるコンクリート中の鉄筋の応力腐食割れと考元られる
表 1 試験体の材料特性

\begin{tabular}{|c|c|c|c|c|c|}
\hline \multirow{2}{*}{ 化学成分 } & $\begin{array}{c}\text { 炭素 } \\
(\%)\end{array}$ & $\begin{array}{c}\text { 珪素 } \\
(\%)\end{array}$ & $\begin{array}{c}\text { マンガン } \\
(\%)\end{array}$ & $\begin{array}{c}\text { りん } \\
(\%)\end{array}$ & $\begin{array}{c}\text { 硫黄 } \\
(\%)\end{array}$ \\
\cline { 2 - 6 } & 0.22 & 0.19 & 0.61 & 0.016 & 0.021 \\
\hline \hline \multirow{3}{*}{ 力学特性 } & $\begin{array}{c}\text { 降伏強さ } \\
\left(\mathrm{N} / \mathrm{mm}^{2}\right)\end{array}$ & $\begin{array}{c}\text { ヤング係数 } \\
\left(10^{5} \mathrm{~N} / \mathrm{mm}^{2}\right)\end{array}$ & $\begin{array}{c}\text { 降伏ひずみ度 } \\
(\%)\end{array}$ & $\begin{array}{c}\text { 引張強さ } \\
\left(\mathrm{N} / \mathrm{mm}^{2}\right)\end{array}$ & $\begin{array}{c}\text { 伸び率 } \\
(\%)\end{array}$ \\
\cline { 2 - 6 } & 386 & 1.88 & 0.205 & 550 & 17.9 \\
\hline
\end{tabular}

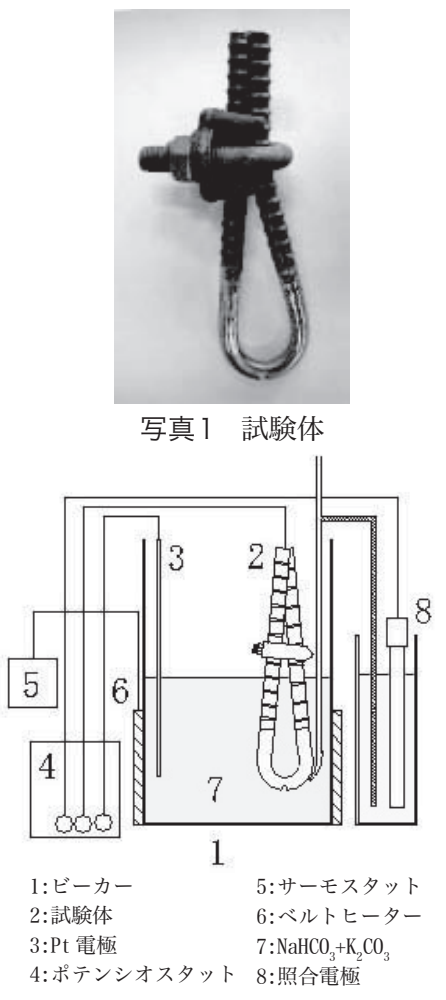

図 1 試験概要

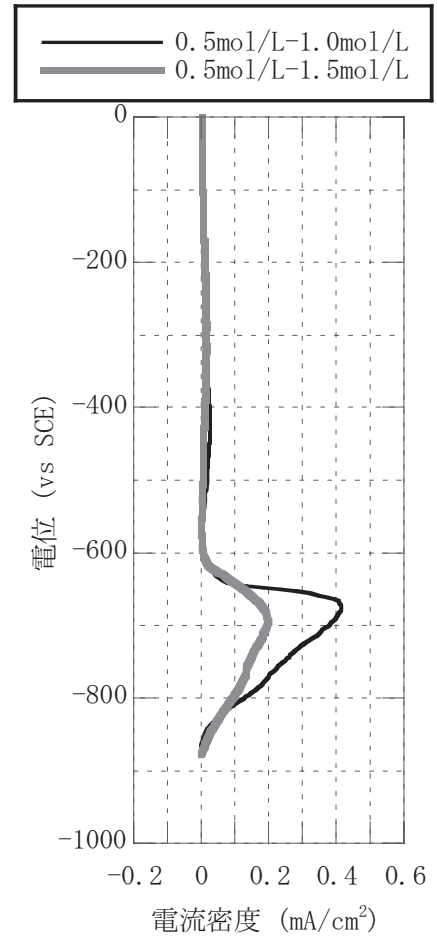

図2 分極曲線
破断は未だに確認されていないが, 炭素鋼全体でみたときに最初に 炭酸塩応力腐食割孔を経験したのは, 1965 年頃を端緒とする, 力 ソード防食された欧米の地下埋設パイプラインにおいてである。カ ソード防食電流によってパイプライン表面に生成する苛性アルカリ と土壤中の $\mathrm{CO}_{2}$ によって生成する $\mathrm{Na}_{2} \mathrm{CO}_{3}-\mathrm{NaHCO}_{3}$ がその原因物質で あった。この場合, 炭酸塩濃度は余り高くないにもかかわらず割れ が発生している。

中性化したコンクリートの場合, 大気からコンクリート中に侵入 した $\mathrm{CO}_{2}$ から当然, 炭酸塩が生成するため, 炭酸塩応力腐食割れの可 能性が生じるわけである。侵入した $\mathrm{CO}_{2}$ の主体はセメント成分である $\mathrm{Ca}(\mathrm{OH}){ }_{2}$ と反応して難溶性の $\mathrm{CaCO}_{3}$ となるが, 一部はイオンとして存 在する可能性がある。その分析例は報告されていないが, 高アルカ リ濃度のセメントを使用したモル夕ル細孔溶液中の $\mathrm{Na}^{+}+\mathrm{K}^{+}$は $0.66 \mathrm{~mol} / \mathrm{L}$ 程度との分析例 ${ }^{14)}$ があり, 試験環境は中性化した $\mathrm{pH}$ に対 応する濃度の $\mathrm{HCO}_{3}{ }^{-}+\mathrm{CO}_{3}{ }^{2-}$ が存在すると仮定した。

パイプラインの事例に対応する炭酸塩応力腐食割れの再現試験は,

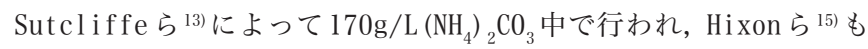
これと同様であるが, 本試験では高アルカリセメントを含むコンク リートを想定して, $\mathrm{K}_{2} \mathrm{CO}_{3}-\mathrm{NaHCO}_{3}$ 系とした。この溶液は中性化の進行 に対応した pH9. 1 と pH9.5である。本試験に用いた溶液の炭酸塩の 濃度は $1.5 \mathrm{~mol} / \mathrm{L}$ と $2.0 \mathrm{~mol} / \mathrm{L}$ であり, 高アルカリのモルタル中の細 


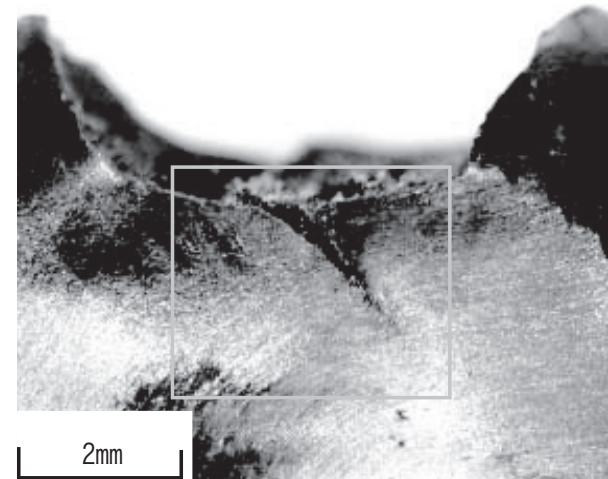

写真2 $0.5 \mathrm{~mol} / \mathrm{L}-1.0 \mathrm{~mol} / \mathrm{L}$ 溶液の試験体の表面

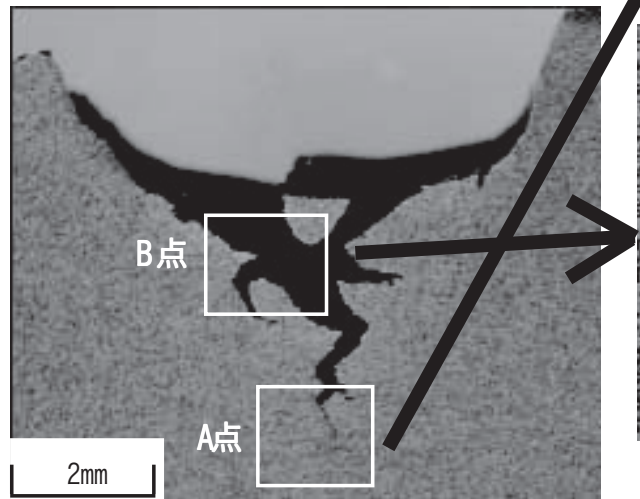

写真3 $0.5 \mathrm{~mol} / \mathrm{L}-1.0 \mathrm{~mol} / \mathrm{L}$ 溶液の試験体の割れ経路

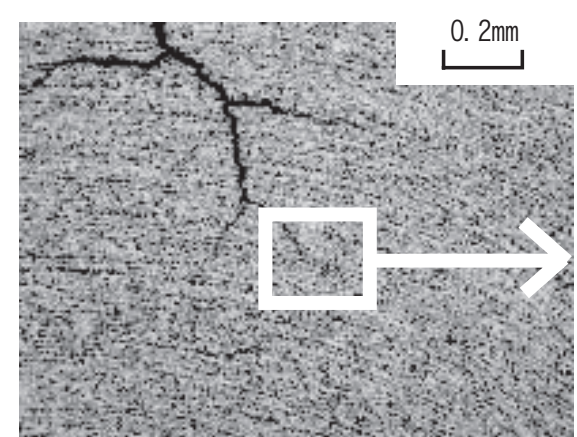

(1) 写真 3 の A 点の拡大

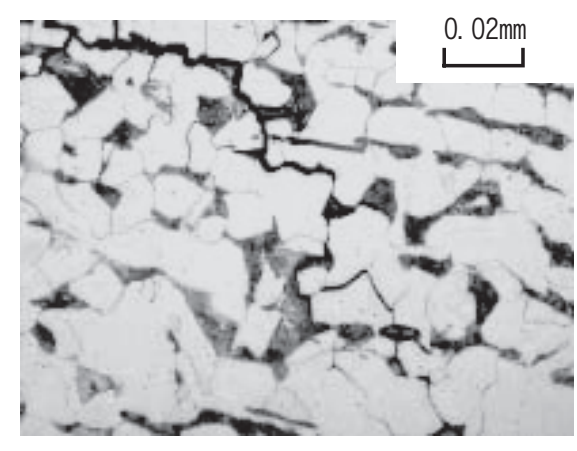

(2) 左図の拡大

写真4 粒界割れの組織写真

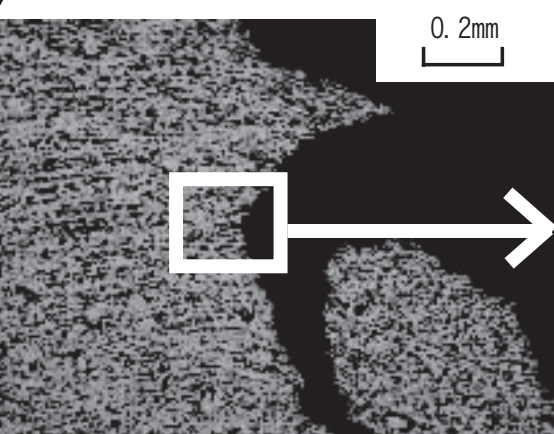

(1) 写真 3 の B点の拡大

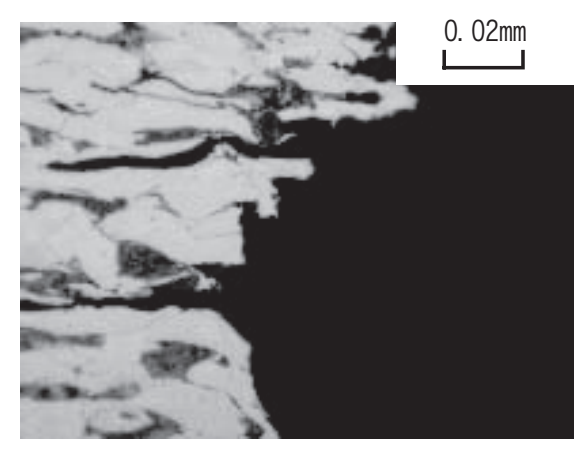

(2) 左図の拡大

写真5 粒内割れの組織写真

孔溶液の分析例 ${ }^{14)}$ を参照した濃度に対して 2.3 倍と 3.0 倍とやや高 い。しかし，黒井 ${ }^{16)}$ ， C. L. Page ら ${ }^{17)}$ はコンクリート中の鋼材に電流 を流したときに炭酸塩を構成するイオンが移動して集積することに よって 6 倍〜 9 倍に濃度上昇することを測定しており，マクロ腐食 電池が生じれば電流が流れるため, アルカリ骨材反応の生じた構造 物では本報で用いた試験溶液の炭酸塩の濃度程度に達することは十 分に考えられる。したがって, 環境的には本試験の結果によってア ルカリ骨材反応が生じた構造物のコンクリート内部の炭酸塩濃度を 再現しているものと考えられる。

\section{2 電位面からの考察}

応力腐食割れはある電位範囲でのみ発生する。多くの応力腐食割 れがその腐食環境における自然電位が割れ発生電位領域内にあるの に対し, 炭酸塩応力腐食割机は炭酸塩環境における自然電位よりも 卑な電位になったときに発生することが知られている な状況となることは少ないので, 炭酸塩応力腐食割れは1965年頃ま で経験されず，カソード防食下のパイプラインという, 電位を人工 的に自然電位よりも卑に設定した系において初めて発見された。

炭酸塩応力腐食割れが発生する電位領域は炭酸塩の濃度や種類に よって異なるが, 報告によれば $170 \mathrm{~g} / \mathrm{L} \quad\left(\mathrm{NH}_{4}\right)_{2} \mathrm{CO}_{3}$ 中で $-500 \mathrm{mV}$ 〜 $-600 \mathrm{mV}$ (vs SCE) ${ }^{13)}, 0.5 \mathrm{~mol} / \mathrm{L} \mathrm{Na}_{2} \mathrm{CO}_{3}-1 \mathrm{~mol} / \mathrm{L} \mathrm{NaHCO}_{3}$ 中では $-650 \mathrm{mV}$ 〜 $875 \mathrm{mV}$ (vs CSE) ${ }^{20)}$ である。このような電位域の決定法の1つが分 極曲線の電流変化領域から求める方法であり ${ }^{13)}$, 本報で用いた 2 種 の溶液中における鉄筋の自然電位は-180mV〜 - 290mV (vs SCE) であっ た。一方, 腐食活性面に対応して酸洗いによって表面皮膜を除去した 鉄筋の電位は, 2 種の溶液に対し $-870 \mathrm{mV} \sim-880 \mathrm{mV}$ (vS SCE) であった。 応力腐食割れが発生しやすい電位を活性面の分極曲線から求めた
值は, $0.5 \mathrm{~mol} / \mathrm{L}-1.0 \mathrm{~mol} / \mathrm{L} て ゙ は-660 \mathrm{mV}$ (vs SCE) , 0.5mol/L-1.5mol/ Lでは-670mv (vs SCE) であり,これらを応力腐食割れ試験のための 設定電位としたが，自然電位よりかなり卑である。これらの值は類 似溶液に対して報告されている炭酸塩応力腐食割れの割れ発生電位 領域 ${ }^{20)}$ に存在する。次にこれらの設定電位がコンクリート中で発現 しうる電位であるかを検討する。

健全なコンクリート中における鉄筋の電位 ${ }^{21)}$ は, アルカリ性環境 を反映して, 飽和硫酸銅電極基準 (以後, vs CSE) で $-200 \mathrm{mV}$ [飽和 カロメル電極基準で約 $-270 \mathrm{mV}$ (vs SCE) ] かそれより貴である。中性 化の進行や塩化物の作用によって腐食が生じる場合には- $360 \mathrm{mV}$ (vs CSE) または $-430 \mathrm{mV}$ (vs SCE) より卑な電位となる。コンクリート中 で塩化物イオンの作用, あるいは塩化物イオン濃度が高くなくても, $\mathrm{pH} 10$ 以下の環境で炭素鋼が腐食するときは一般にアノード活性面の 開路電位は $-760 \mathrm{mV} \sim-780 \mathrm{mV}$ (vS SCE) ${ }^{22)}$ であるが，実際に測定され る電位は不動態化した鉄筋との混成電位である。腐食していると推 定される鉄筋について報告されている電位測定結果 ${ }^{23)}$, 24) は-450mV〜 $-600 \mathrm{mv}$ (vs SCE) であり, 塩化物イオン濃度が高いなどの結果, 腐食 が激しい場合ほど電位は卑である。これらの電位はコンクリート表 面等の腐食部, 非腐食部に対して必ずしも近くない位置の, いわゆ るリモート位置で測定した混成電位であり, 実際の腐食部ごく近傍 の電位ではない。腐食が完全に活性化している時の炭素鋼の電位は $-760 \mathrm{mV} \sim-780 \mathrm{mV}(\mathrm{vs} S \mathrm{SCE}){ }^{22)}$ であり，この近傍の真の電位は限りな く $-760 \mathrm{mV} \sim-780 \mathrm{mV}$ (vs SCE) に近づく。したがって, 本試験で用い た $-660 \mathrm{mV}$ (vs SCE) , $-670 \mathrm{mV}$ (vs SCE) は十分存在しうる電位である。 以上のように, 本試験条件での割れの発生は, 付加した電位の面 からもコンクリート中の鉄筋に炭酸塩応力腐食割れが生じる可能性 
があることを示めしている。

\section{3 割れ経路からの考察}

パイプラインの炭酸塩応力腐食割れ事例においては, 割机は粒界 型であるとの報告が多いが，粒界-粒内混合型になる場合もあると 報告されている ${ }^{18)}$ 。本研究に係わる鉄筋の割れ事例の報告では，粒 界-粒内混合型と考えられるもの ${ }^{10)}$ のほかに, 粒内型とするもの1 もあり，定説はない。しかし，混合型であるとの考えに従えば，本 試験で再現させた割れは経路の面で報告事例と一致することから， アルカリ骨材反応の生じたコンクリート中の鉄筋には炭酸塩応力腐 食割れの生じる可能性が高いといえる。

Parkins ${ }^{18)}$ によれば, 炭酸塩応力腐食割れが結晶粒を貫通して進行 するのは，応力集中が高く，しかも環境条件が弱い場合である。本 試験の付加応力の大きさは事例の鉄筋の受けていた応力が不明であり 曲げ半径が異なるので直接的な比較は行えないが, 試験体の応力集中 はかなり高いものであったにもかかわらず，環境条件が比較的強 かったことから，割れ経路は混合型になったと考えられる。粒内型 を主体とする事例が確認された場合は, 中性化及びアルカリ骨材反 応が低度であり，環境条件が弱かったことによる可能性がある。健 全な状態に近いコンクリート中の鉄筋においても, 炭酸塩応力腐食 割れの生じる可能性を否定することはできない。

\section{4. 水素脆化が生じる可能性}

4. 1 環境面からの考察

従来，水素脆化が生じた事例 ${ }^{25)}$ は，硫化水素を含む酸性環境では 強度 $700 \mathrm{~N} / \mathrm{mm}^{2}$ 以上の油井チュービング等の割れ, 中性環境では強度 $1100 \mathrm{~N} / \mathrm{mm}^{2}$ 以上の高力ボルトの割れである。いずれの材料も, SD295A の鉄筋よりはるかに高強度の調質鋼であり, 水素イオン濃度が低い 中性環境では非常に高強度でないと水素脆化が生じず, 過去の事例に も見当たらない。したがって, 水素イオンが更に低いアルカリ環境で あるコンクリート中で, SD295A程度の強度の鉄筋に水素脆化の生じ る可能性は極めて低いと考えられる。

\section{2 割れ経路からの考察}

破断事例の鉄筋の割机経路には粒界に沿う部分が見出されており ${ }^{10)}$, 水素脆化の割れ経路は粒内型が一般的であることを考えれば, 割れ 経路の観点からも水素脆化による割机が生じる可能性は低い。

\section{3 材料の割れ感受性}

強度, 環境面および割れ経路からの考察ではアルカリ骨材反応の 生じたコンクリート中に水素脆化の生じる可能性は低いが, 水素脆 化を原因として予想する文献 ${ }^{1}$ があることから, 基本的な問題とし てSD295A に水素脆化による割机が生じうるか否かを調べるため, 極女て強い促進条件下で水素脆化試験を行い, 割机感受性を調査し た。

\section{(1) 試験概要}

試験体は表 1 の異形鉄筋 D13 (SD295A) のリブと節を除去したのち 500 番の研磨紙で直径 $11.6 \mathrm{~mm}$ まで磨き, 曲げ半径 $15 \mathrm{~mm}$ (直径の 1.3 倍) で 180 度に曲げて，金具によって端部を固定しU字型試験体を作製 した。割れ感受性は図 3 のように $5 \%$ 硫酸溶液(触媒毒として $0.2 \%$ の チ才尿素を添加) で水素チャージを行うことによって確かめた。水素 チャージは $8 \mathrm{~mA} / \mathrm{cm}^{2}$ の電流密度で行った。

(2) 試験結果および考察
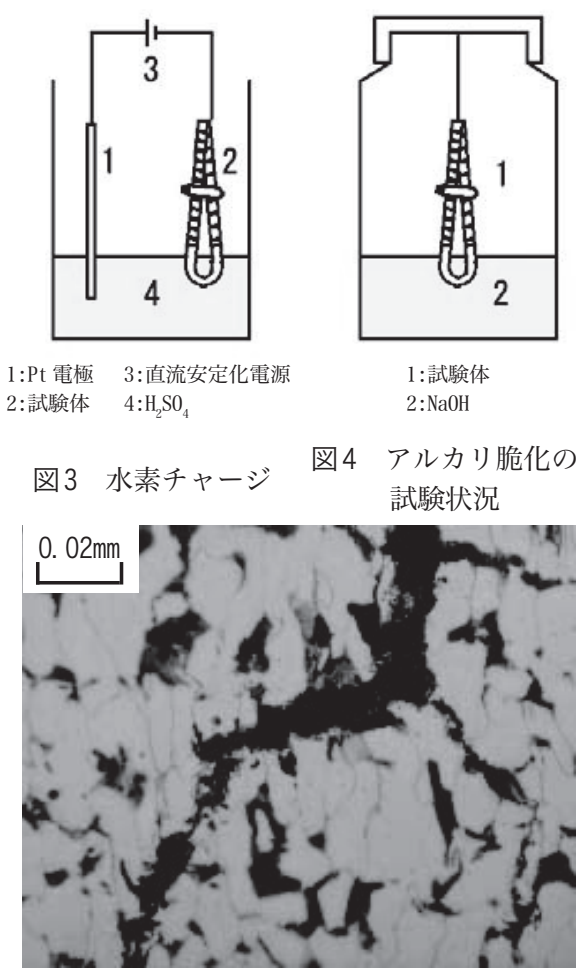

写真6 水素脆化試験後の組織写真 (粒内割れ)

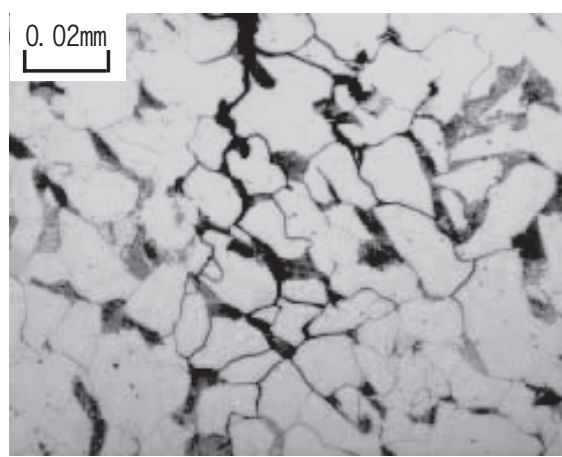

写真 7 アルカリ脆化試験後の組織写真 (粒界割れ)

割れによる破断は 30 時間程度で発生した。従来，水素脆化による 割れ感受性は焼入れ焼戻し型の高張力鋼で問題となるが, SD295Aの ように引張強さが $550 \mathrm{~N} / \mathrm{mm}^{2}$ と比較的低強度のフェライトーパーライ 卜組織の鋼材でも, 水素チャージにより水素脆化による割れが生じ ることが分かった。割れ経路は写真 6 に示すように粒内型である。 SD295Aに水素脆化による割れ感受性のあることが分かったが, コ ンクリートのように水素イオン濃度が極めて低い環境中で, この程 度の強度の鋼では水素脆化による割机が自然に生じるとは考えにく w。

\section{5. アルカリ脆化が生じる可能性}

5.1 環境面からの考察

アルカリ脆化の事例は苛性アルカリの貯蔵タンクに多い。この割 れには鋼材の強度は直接関係しないが，苛性ソーダの場合，割れが 生じるのは濃度 $30 \%$ で温度 $60^{\circ} \mathrm{C}$ 以上， $10 \%$ で $80^{\circ} \mathrm{C}$ 以，それ以下の 
濃度では割れても非常に高温の場合である ${ }^{26)}$ と報告されている。し たがって, コンクリート中では, アルカリ濃度, 温度的にこの種の 割れが生じるとは考えにくく，過去の事例にも見当たらない。

\section{2 割れ経路からの考察}

破断事例の鉄筋の割孔経路は，粒界-粒内混合型 ${ }^{10)}$ と考元られる もののほかに粒内型とする報告1)さえあり，アルカリ脆化の割れ経 路は粒界型が一般的であることを考えれば, 割れ経路の観点からも アルカリ脆化の生じる可能性は低い。

\section{3 材料の割れ感受性}

環境面および割れ経路からの考察ではアルカリ骨材反応の生じた コンクリート中にアルカリ脆化の生じる可能性は低いが, SD295Aに ついてアルカリ脆化の割机感受性を調査した。

\section{(1) 試験概要}

試験体は炭酸塩応力腐食割れと同じ加工の異形鉄筋を用いた。試 験体は図 4 のように, 密閉容器に入れた水酸化ナトリウム溶液中に 吊して, 次の試験環境に制御した恒温器の中に入れた。試験環境は 濃度 $50 \%(17 \mathrm{~mol} / \mathrm{L})$ の溶液で温度 $90^{\circ} \mathrm{C}$ と $70^{\circ} \mathrm{C}, 40 \%(13 \mathrm{~mol} / \mathrm{L})$ の溶液 で $90^{\circ} \mathrm{C} と 70^{\circ} \mathrm{C}, 30 \%(9 \mathrm{~mol} / \mathrm{L})$ の溶液で $90^{\circ} \mathrm{C}$ に制御し, 試験開始から 200時間経過したのち, 割れの有無を目視によって調査した。溶液に は $0.2 \% の$ 酸化鉛を入れて割れ感受性を高めた。

\section{(2) 試験結果および考察}

$50 \%$ の溶液では $90^{\circ} \mathrm{C}$ と $70^{\circ} \mathrm{C}, 40 \%$ の溶液では $90^{\circ} \mathrm{C}$ ときに割れが 生じ，アルカリ脆化は濃度が高いほど低い温度で生じる。割れ経路 は写真 7 に示すように粒界型である。コンクリート中ではアルカリ 濃度, 温度的にアルカリ脆化が生じるとは考えにくい。

\section{6. まとめ}

鉄筋 D 13 (SD295A) の炭酸塩応力腐食割れを，中性化したコンク リートを模擬した実験室環境中で再現させ，コンクリート中の鉄筋 が炭酸塩応力腐食割れを生じる可能性があることを示した。併せて, 水素脆化及びアルカリ脆化による割れについて試験を行い, それら の腐食割れはコンクリート中の鉄筋で生じる可能性は低いことを示 した。

(1) 炭酸塩応力腐食割れを再現させた試験環境は炭酸塩濃度が $1.5 \mathrm{~mol} / \mathrm{L} \sim 2.0 \mathrm{~mol} / \mathrm{L}$ であり, 中性化が進んだコンクリート中 で発現しうる濃度である。

(2) 割れは $-660 \mathrm{mV}$ (vs SCE) と-670mv (vs SCE) の定電位付加の条 件で生じた。これは鉄筋の腐食が進むコンクリート中で発現し うる電位である。

(3) 割れ経路は粒界-粒内混合型であり,これは文献10)からの推定 経路と一致する。

(4) 引張力が付加されなければ応力腐食割れは生じないが, 破断事 例のせん断補強筋の曲げ加工部では大きな引張力を受けていた と推定されるので腐食割れの生じた可能性が高い。

（5）水素脆化及びアルカリ脆化による割れの可能性は環境面及び割 れ経路の考察から否定できるが, 極めて強い促進環境下の試験 ではSD295Aに割れ感受性が存在することを補足的に確認した。

今後は割れが生じる付加応力や濃度の限界值を解明していくこと によって, 炭酸塩応力腐食割れの生じうる条件を特定していきたい。
謝辞

本研究を実施するに当たり，JFEスチール 鹿毛勇氏，群馬県立群馬 産業技術センター 薄波圭司氏, 元 前橋工科大学卒論生 内田加奈子 氏, 中村由佳氏, 中道愛友氏, 山科美和氏に協力を得た。ここに記し て感謝の意を表す。

\section{参考文献}

1) 土木学会:アルカリ骨材反応対策小委員会報告書, コンクリートライブラリー, 124 号, 2004

2) 小林一輔:高張力異形鉄筋の実験的研究, 土木学会論文集, 第 89 号, pp. 1130, 1963

3) 赤塚雄三, 関 博:港湾構造物における高張力異形鉄筋の使用方法に関する調 査研究 (第 1 報), 港研報告, Vol.5, No. 15, pp. 1-46, 1966

4) 山中憲行, 林 貞夫:過大なコンクリートの膨張力が生じたRC構造のせん断補 強筋の変形性状，セメント・コンクリート論文集，No.60, pp.426-433, 2006

5) 中島俊和, 久保善司, 鳥居和之:ASR膨張がコンクリート構造物の鉄筋破断に 与える影響, コンクリート工学年次論文集, Vol.25, pp. 1535-1540, 2003

6) Aziz Asphahani and H.H.Uhlig:Stress Corrosion Cracking of 4140 High Strength Steel in Aqueous Solution, J. Electrochem. Soc., Vol. 122, No. 2, pp. 174-179, 1975.2

7) E.H.Phelps:Stress-Corrosion Behavior of High Yield-Strength Steels, Proc. 7th World Petroleum Congress, pp.201-209, 1967

8) B. Poulson:The Fractography of Stress Corrosion Cracking in Carbon Steels, Corrosion Science, Vol.15, pp.469-477, 1975

9) 小林一輔, 星野富夫:アルカリ骨材反応によって劣化した或る大規模集合住宅 の調査，コンクリート工学年次論文集，Vol.8, pp. 857-859, 1986

10) 佐々木一則, 西岡敬治, 南敏和, 宮川豊章:アルカリ骨材反応による鉄筋損 傷の原因究明に関する調査報告，コンクリート構造物の補修，補強，アップ グレート論文報告集，第 4 巻，pp. 81-88，2004. 10

11) 小若正倫:新版 金属の腐食損傷と防食技術，アグネ承風社，1995

12) JIS G0576:ステンレス鋼の応力腐食割れ試験方法，2001

13) J. M. SUCTLIFE, R. R. FRSSLER, W. K. BODY and R. N. Pakins:Stress Corrosion Cracking of Carbon Steel in Carbonate Solutions, Corrosion, Vol.28, No. 8, pp. 313-320, 1972.8

14）小野紘一, 川村満紀, 田村 博, 中野錦一:アルカリ骨材反応, 技報堂出版, 1986

15) DONALD HIXSON and H.H. UHLIG:Stress Corrosion Cracking of Mild Steel in Ammonium Carbonate Solution, Corrosion, Vol.32, No.2, pp.56-59, 1976.2

16) 黒井登紀雄:電気分解による鉄筋コンクリートの劣化に関する基礎研究，土 木学会論文集，第 402号，V-10, pp. 33-42, 1989

17) C. L.Page, G. Sergi and D. M. Thompson:Development of Alkal i-Silica Reaction in Reinforced Concrete subjected to Cathodic Protection, Proc. of the 9th Inter. Conf. on Alkali -aggregate Reaction in Concrete, pp. 774781,1992

18) R.N. Pakins:Stress Corrosion Cracking, Uhl ig's Corroanosion Handbook, pp. 191-204, 2000

19) H.H.Uhl ig and R.Winston Revie:Corrosion and Corrosion Control, WileyInterscince, 1997

20) 笠原晃明, 佐藤泰作:ラインパイプ用鋼の応力腐食割れ感受性に及ぼす環境 因子の影響，鉄と鋼，Vol.69，No. 11，pp. 1463-1470，1983

21) ASTM C 876-91:Standard Test Method for Half Cell Potentials of Reinforcing Steel in Concrete, 1991

22）松島䉷, 上野忠之:鋼の海水腐食の基礎的研究 (第 1 報)さび層の保護性につ いて，防蝕技術，Vol.19， No.13，pp. 10-16，1970

23）岩田亮，Qi Lukuan, 関博: 中性化したコンクリート中における鉄筋腐食機 構の電気化学的考察, コンクリート工学年次論文集, Vol.22, No. 1, pp. 181186, 2000

24) 鈴木僚ほか 5 名:測定環境条件が鉄筋コンクリートの電気化学的測定結果に 及ぼす影響，生産研究，第 59 巻，第 3 号, pp. 267-270, 2007

25) 松山晋作:遅れ破壊, 日刊工業新聞社, 1989

26) H.W.Schmidt, P. J. Gerger, G.Heinemann, C.F.Pogacar and E.H. Wyche: Stress Corrosion Cracking in Alkaline Solutions, NACE Technical practices commitee reports Corrosin 7,pp. 295-302, 1951 